Available online at

http://www.anpad.org.br/bar

BAR, Curitiba, v. 7, n. 1, art. 3,

pp. 40-58, Jan./Mar. 2010

\title{
Antecedents and Consequences of Market Orientation: a Brazilian Meta-Analysis and an International Mega-Analysis
}

\author{
Valter Afonso Vieira * \\ E-mail address: valterafonsovieira@ yahoo.com \\ Universidade Federal do Paraná - CEPPAD/UFPR \\ Curitiba, PR, Brazil.
}

\begin{abstract}
Market orientation has emerged as a significant antecedent of organizational performance and is presumed to contribute to the long-term success of a firm. The growing number of academic studies on market orientation and the mixed findings they have reported complicate the efforts among managers and academics to identify the real antecedents and outcomes of this construct. We have conducted a Brazilian meta-analysis, aggregating a sample size of 4,537 in 27 papers. The findings suggest that the relationship between market orientation and business performance is positive and strong $(r=.39)$. We have also conducted an international mega-analysis, aggregating a sample size of seven meta-analyses on market orientation. The results show that there is a positive, strong and consistent international relationship between market orientation and performance across countries $(r=$ $.33)$.
\end{abstract}

Key words: market orientation; meta-analysis; mega-analysis; Brazil; international.

Copyright (C) 2010 Brazilian Administration Review. All rights reserved, including rights for translation. Parts of this work may be quoted without prior knowledge on the condition that the source is identified.

\footnotetext{
* Corresponding author: Valter Afonso Vieira

Rua Viuvinha, 69, Arapongas, PR, 86709-340, Brazil.
} 


\section{INTRODUCTION}

In the marketing concept, Market Orientation is a relevant topic for studying and comprehending the behavior of firms. In the marketing field, the early studies of Kohli and Jaworski $(1990,1993)$ and Narver and Slater $(1990,1995)$ stand out. Market orientation involves an implementation of the marketing concept since it facilitates firms' ability to anticipate, react to and capitalize on environmental changes, thereby leading to superior performance (Shoham, Rose, \& Kropp, 2005).

In the evolution of the market orientation concept, two approaches have been adopted in the literature (Homburg \& Pflesser, 2000). The first identifies three main components of the construct: an organization-wide generation of market information about current and future customer needs; a dissemination of such information across departments and individuals within the market-oriented firm, and an organization-wide responsiveness to the disseminated information (Jaworski \& Kohli, 1993, 1996; Kohli \& Jaworski, 1990, 1993). This behavioral perspective concentrates on organizational and human activities that are related to the creation, propagation of, and reaction to market intelligence (Kirca, Jayachandran, \& Bearden, 2005).

The second approach is a cultural perspective that focuses on organizational norms and values that encourage behaviors that are consistent with market orientation (Narver \& Slater, 1990, 1995). In this last point of view, Narver and Slater (1990) present market orientation as a construct created from three main elements: customer orientation; which is firms' focus on client needs; competitor orientation, which analyzes the opponent strategy and market movement; and inter-functional coordination, which introduces cooperation among employees. In these circumstances, both market orientation approaches are complementary in explaining the behavior of firms.

The Brazilian market orientation literature has some limitations. Throughout the past two decades researchers have investigated several antecedents and consequences of market orientation to better understand its role in organizations and markets. Furthermore, despite a significant volume of research on the relationship between market orientation and business performance, findings regarding this relationship often vary substantially in terms of magnitude. As a result, the literature shows mixed outcomes of the association. For instance, these results vary from non significant (Müller Neto, 2005) or negative (Bhuian, 1997) to positive (Jaworski \& Kohli, 1996; Slater \& Narver, 1994a, 1994b). As a possible solution to these miscellaneous results, a meta-analysis can provide insights into theses inconsistencies by identifying measurement and sample characteristics that affect the market orientation-performance relationship and by assessing the generalizability of the outcomes (Brown \& Peterson, 1993).

In parallel, the international market orientation literature has been producing different meta-analytic analysis of the phenomenon, which limits the analysis of the results. These international studies found that market orientation construct is an antecedent of the new product projects (Pattikawa, Verwaal, \& Commandeur, 2006), performance (Kirca et al., 2005), performance for not-for-profit compared to profit firms and service compared to manufacturing firms (Cano, Carrillat, \& Jaramillo, 2004), performance of the voluntary and nonprofit organizations (Shoham et al., 2005), and is significantly affected by cultural and economic characteristics of the host country (Ellis, 2006).

We can see some different global variables affecting market orientation. Early studies of the relationship between market orientation and business performance are limited to research conducted in the United States and, to a lesser extent, the United Kingdom (Bhuian, 1997; Cano et al., 2004; Deshpandé \& Farley, 1998). Empirical studies incorporating samples from multiple countries are sparse (e.g., Deshpandé, Farley, \& Webster, 1997; Hooley et al., 2000). Thus, aggregating a national meta-analysis with other meta-analyses using an international mega-analysis might consolidate research findings in the literature. Thus, the study does summarize the effect of the most widely examined international market orientation on performance relationships across countries. Based on these concerns, this research seeks answers to the following questions: 
1) What is the mean impact of market orientation on performance in Brazil?

2) What are the study characteristics that moderate the overall relationship between market orientation and performance?

3) What is the mean impact of international market orientation on its consequences using megaanalysis?

This paper is structured as follows: first, it reviews the market orientation literature, adapting a theoretical model of its antecedents and consequences. In the next part, we present the method. Then, we answer the first two questions. After that, we present the mega-analysis methodology, collecting data from seven meta-analytic papers specific to market orientation. Then, we answer the third question. As a result, we collected data from nine meta-analytic papers on management research. Hence, we do an international and comparative examination of these studies, answering the last question. Subsequently, the paper presents general conclusions.

\section{ADJUSTED BRAZILIAN THEORETICAL FRAMEWORK}

This research adjusts the framework proposed by Kirca et al. (2005), which depicts the relationships among the most frequently examined antecedents and consequences of market orientation. Since data collected in Brazil is not sufficient to examine all relationships originally proposed by Kirca et al. (2005), the paper has limitations. For instance, the articles collected measure neither the consequences of market orientation, such as quality, customer loyalty and role conflict, nor the antecedents of market orientation, such as interdepartmental conflict and market-based reward systems. In that sense, Figure 1 presents the adjusted theoretical model.

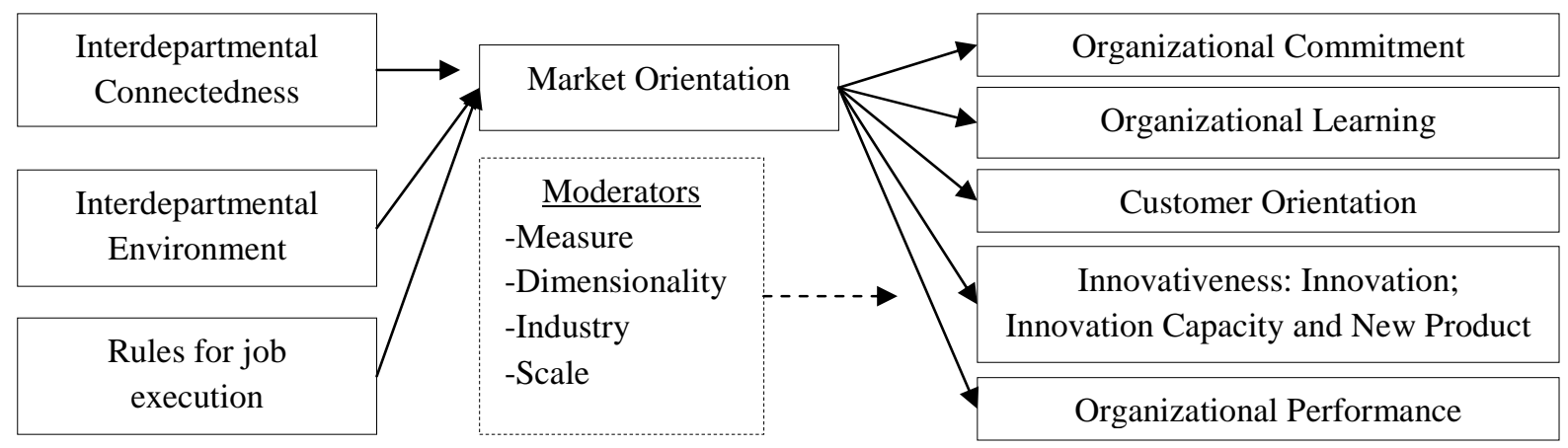

Figure 1: Antecedents and Consequences of Market Orientation: Adjusted Brazilian Model Source: author based on Kirca, A. H., Jayachandran, S., \& Bearden, W. (2005). Market orientation: a meta-analytic review and assessment of its antecedents and impact on performance. Journal of Marketing, 69(2), 26.

\section{ANTECEDENTS OF MARKET ORIENTATION: HyPOTHESES}

Interdepartmental Connectedness. Interdepartmental Connectedness is the extension of formal and informal contacts among employees across various departments. We hypothesized that this unofficial contact enhances market orientation by leading to greater sharing and use of information among workers (Kirca et al., 2005). Specifically, the literature suggests that an organization that adopts a customer orientation, by understanding the roles of leadership and interfunctional coordination, and by collecting and disseminating the customer-focused data in the transformation process, tends to increase its interdepartmental connectedness toward the market (Kennedy, Goolsby, 
\& Arnould, 2003). If there is more association among departments, workers tend to be more integrated when it comes to meeting customers' demands. In that sense, we hypothesized that $\mathrm{H}_{1 \mathrm{a}}$ : there is a positive relationship between interdepartmental connectedness and market orientation.

Interdepartmental Environment. Interdepartmental environment means those aspects of firms' surroundings and work-style that help employees to carry out their daily tasks as best as possible. This friendly surrounding creates more life-quality at workplace (Slongo \& Bossardi, 2004) and harmony to the overall organization. The interdepartmental environment construct figures out as the formal and informal atmosphere created among employees across departments while doing their jobs. In fact, a positive atmosphere might reduce the tension between departments and increase the focus on process, market and consumers. The assumption is that an environment that provides employees with a sense of belonging to the firm's philosophy, a feeling of contributing towards satisfying customers' needs and a sense of greater "esprit de corps" and social benefits to employees (Shoham et al., 2005) increases the focus on market orientation. Because of that, we assume that $\mathrm{H}_{1 \mathrm{~b}}$ : there is a positive relationship between interdepartmental environment and market orientation.

Rules for Job Execution. Rules for job execution are the top management's emphasis on the conditions and roles necessary for workers to execute their daily tasks, such as the behavior of employees in an autocratic process for attending clients (Costa, 2006). The theory suggests that formalization, which refers to the explanation of rules, procedures and authority through regulations, is negatively related to market orientation because it inhibits firms' information use and the development of effective responses to changes in the marketplace (Jaworski \& Kohli, 1993; Kirca et al., 2005). The hypothesis suggested here is a U-shaped inverted relationship between formalization and market orientation, assuming not a negative but a positive association. The argument is that the degree of formalization (Gonçalves, Gonçalves, \& Veiga, 2002), regulation and control (Dalmoro \& Faleiro, 2007) in doing work generates more focus on the correct tasks. In that sense, these rules (as used in Révillion, 2005) aid firms' development of effective job execution, helping meet consumers' needs.

Instead of harming the market orientation focus (negative relationship), rules for job execution help firms to focus more on the market and clients. The argument is that by creating rules, employees might feel more secure in carrying out their tasks and more secure about which actions may be in agreement with firms' philosophy and norms. Because of this, more formalization should improve the market orientation (positive relation), but when it arrives at a specific point, the excess of formalization should decrease the market orientation ability (negative association), assuming a curvilinear relationship. In that circumstance, it is hypothesized that $\mathrm{H}_{1 \mathrm{c}}$ : there is a positive relationship between rules for job execution and market orientation.

\section{CONSEQUENCES OF MARKET ORIENTATION: HYPOTHESES}

Commitment. Kohli and Jaworski (1990) argue that by spreading a sense of pride and camaraderie among employees, market orientation enhances organizational commitment, employee-team spirit and customer orientation. Shoham et al. (2005) comment that committed employees (a) are less likely to be absent from work or to resign from their firms, (b) are more likely to go beyond required norms to contribute to the attainment of organizational goals and (c) are willing to put more effort into the wellbeing of the organization. Because of these features, organizational commitment should be positively associated with market orientation. In that situation, we hypothesized that $\mathrm{H}_{2}$ : there is a positive relationship between commitment and market orientation.

Learning. Learning is the acquisition, interpretation and dissemination of the organizational information inside firms' culture (Slater \& Narver, 1995). Learning is a cultural process accumulated by the organization and circulated within its firms. Farrell (2000) and Hurley and Hult (1998) supported the association between market orientation and learning, commenting that learning is a 
cultural feature of the organization that deals with marketing and customer demands. In that situation, we assumed that $\mathrm{H}_{3}$ : there is a positive relationship between learning and market orientation.

Customer Orientation. The market orientation essence is the customer's needs. Customer orientation includes more quality in products, firm's commitment, positive word-of-mouth, consumer satisfaction and loyalty. Market orientation enhances customer satisfaction and loyalty because firms are well positioned to anticipate customer needs and offer goods and services to satisfy those needs (Slater \& Narver, 1994b). In that sense, the organization is in line with the market demands, providing more perceived value. The market orientation does not focus solely on customers, but they are the core aspect of the construct. Research has found a significant and positive association between market orientation and customer orientation (Jaworski \& Kohli, 1993, 1996; Kirca et al., 2005; Slater \& Narver, 1994a, 1994b). From the evidence, we hypothesized that $\mathrm{H}_{4}$ : there is a positive relationship between market orientation and customer orientation.

Innovation. Innovation consequences include firms' innovativeness and the ability to create and implement new ideas, products and processes (Hult \& Ketchen, 2001). Market orientation should enhance an organization's innovativeness and new product performance since innovation drives a continuous and proactive disposition toward meeting customer needs and emphasizes greater use of information (Han, Kim, \& Srivastava, 1998). For organizations, the notion that consumers have different needs and demand different products suggests more investments in $R \& D$, generating more innovative products.

Based on the arguments discussed and the empirical evidence that follows, we suggest that $\mathrm{H}_{5 \mathrm{a}}$ : there is a positive relationship between market orientation and innovation (Han et al., 1998; Hult \& Ketchen, 2001); $\mathrm{H}_{5 \mathrm{~b}}$ : there is a positive relationship between market orientation and new product performance (Damanpour, 1991; Im \& Workman, 2004; Perin \& Sampaio, 2003; Perin, Sampaio, \& Hooley, 2006); and $\mathrm{H}_{5 \mathrm{c}}$ : there is a positive relationship between market orientation and market innovation capacity (Gonçalves et al., 2002; Kirca et al., 2005).

Performance. Because market orientation helps firms track and respond to changing customer needs, it should be associated with business performance. Literature suggests that firms manage their relationship with the environment in order to maximize their performance (Shoham et al., 2005). Resource Based View Theory postulates that differential firm resources give rise to superior strategy and performance (Barney, 1991). Because market orientation helps firms to improve their resources and is a market differential, the investments on this strategy should result in superior performance (Perin, Sampaio, \& Henriqson, 2005). Thus, we hypothesize that $\mathrm{H}_{6}$ : there is a positive relationship between market orientation and performance (Deshpandé \& Farley, 1998; Kohli \& Jaworski, 1990; Slater \& Narver, 1994b; Urdan, 2000, 2001a, 2001b).

In this study, we measure performance in two forms: Subjective Likert-scale and Objective scale. In the latter, the variables were sales, profit, sales-by-employee, profit and market share. When there is more than one way of measuring objective performance, for instance the market share, sales and profit as used in Sampaio et al. (2005), this meta-analysis uses the average of the correlations to create a global performance indicator. The next topic discusses Study 1.

\section{STUdY 1: BRAZILIAN META-ANALYSIS}

Methodology. An extensive search was performed where the data base searched the CAPES Dissertation Site, Proquest, Brazilian Universities Libraries, Google Scholar, Brazilian top Business Journals and Business Conferences (Qualis-CAPES Accreditation). We used the following key terms in the database: market, orientation, performance, and customer. Additionally, the more prolific Brazilian authors of this topic were asked for working papers that they had not published. Six researchers sent their unpublished data. The only inclusion criterion was that studies reported 
statistical information sufficient to calculate an effect size. When the same article was published at a conference and in a journal, we use the journal reference (excluded if paper was duplicated).

Sample. The 27 Brazilian articles used in this meta-analysis are: Antoni (2004), Carvalho (2001), Costa (2006), Dalmoro and Faleiro (2007), Faleiro (2001), Galão, Pacagnan, Silva and Frutos (2007), Gava and Silveira (2007), Gonçalves et al. (2002), Mandelli (1998), Menna (2001), Müller Neto (2005), Perin (2002), Perin and Sampaio (2001, 2003, 2006), Perin, Sampaio and Faleiro (2002), Perin et al. (2005), Perin et al. (2006), Révillion (2005), Sampaio (2000), Santos and Rossi (2005), Silva, Damacena and Melo (2002), Slongo and Bossardi (2004), Souza (2004) and Urdan (2000, 2001a, 2001b).

Effect Size Calculation. We selected the correlation coefficient $r$ as the primary effect size metric because it is easier to interpret and is a scale-free measure. Effect sizes are obtained through a range of statistical data (e.g., Student's $t, F$ ratios with one $d . f$. in the numerator, $\chi^{2}$ ) by means of the formulas given by Hunter and Schmidt (2004). Not all the empirical studies, however, reported correlations or measures that could be converted into correlations.

This author therefore asked researchers to report the correlations or send their database. In a few instances, the authors were able to offer the correlations requested. This paper does not transform the product-moment correlation $(r)$ into a Fisher's $Z_{r}=(.5[\ln (1+r)-\ln (1-r)])$ because that transformation introduces more error than the original value in $r$ (Hunter \& Schmidt, 2004).

Meta-Analysis Findings. Table 1 summarizes the bivariate correlations and other statistics for the relationships between market orientation and its antecedents and consequences. When a study contained two or more samples, it was analyzed separately (see Gava \& Silveira, 2007; Menna, 2001; Perin \& Sampaio, 2003; Urdan, 2000).

Antecedents of Market Orientation. The data showed that all three antecedents of market

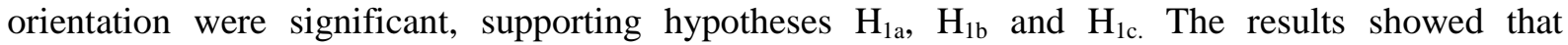
interdepartmental connectedness had a significant and positive impact on market orientation $(r=.64$; $p<.000)$. Note that interdepartmental connectedness accounted for $41 \%\left(r^{2}\right)$ of the market orientation variance. We can see that interdepartmental connectedness was the most important construct in explaining market orientation variation. This evidence supports the cultural perspective that focuses on organizational norms and interchange values (Deshpandé \& Farley, 1998). Some examples of the variables used for measuring interdepartmental connectedness in this meta-analysis are: opinion sharing (Perin, 2002), employees' opportunity to give opinions (Gonçalves et al., 2002), department connectedness (Santos \& Rossi, 2005), communication among employees across various departments (Perin \& Sampaio, 2006; Slongo \& Bossardi, 2004), etc. 
Table 1

Overview of Antecedents and Consequences of Market Orientation

\begin{tabular}{|c|c|c|c|c|c|c|c|c|c|c|c|c|c|}
\hline Construct Hypothesis & $\boldsymbol{K}$ & $N$ & $\boldsymbol{O}$ & Range of $r$ & $\begin{array}{c}\text { Simple } \\
\text { Average } \\
r\end{array}$ & $\begin{array}{c}\text { Sample } \\
\text { Weighted } \\
\text { Adjusted } \\
r\end{array}$ & $\begin{array}{c}\text { Effect } \\
\text { Size }\end{array}$ & $\mathbf{S}_{\text {Error }}$ & $\mathbf{L}_{\mathbf{C I}}$ & $\mathbf{U}_{\mathbf{C I}}$ & $Q$-Test & $\begin{array}{c}\% \\
\text { Acc. }\end{array}$ & $\begin{array}{c}\text { File } \\
\text { Drawer }\end{array}$ \\
\hline \multicolumn{14}{|l|}{ Antecedents of Market Orientation } \\
\hline \multicolumn{14}{|l|}{ Interdepartmental Dynamics } \\
\hline Interdepartmental Connectedness $(\alpha=.71)$ & 6 & 1,138 & 6 & .15 to .77 & .53 & .55 & $.64 * * *$ & .02 & .61 & .68 & $111 * * *$ & $5 \%$ & 70 \\
\hline Interdepartmental Environment $(\alpha=.92)$ & 2 & 579 & 2 & .38 to .58 & .43 & .45 & $.53^{*}$ & .03 & .47 & .59 & $22 * * *$ & $4 \%$ & $\mathrm{NC}$ \\
\hline Rules for Job Execution $(\alpha=.77)$ & 5 & 1,293 & 5 & .24 to .38 & .30 & .33 & $.40 * * *$ & .02 & .35 & .44 & 6 & $41 \%$ & 35 \\
\hline \multicolumn{14}{|l|}{ Consequences of Market Orientation } \\
\hline \multicolumn{14}{|l|}{ Organizational Consequences } \\
\hline Organizational Commitment $(\alpha=.62)$ & 2 & 148 & 2 & .51 to .66 & .58 & .53 & $.78 *$ & .05 & .72 & .84 & $4 *$ & $28 \%$ & $\mathrm{NC}$ \\
\hline Learning $(\alpha=.88)$ & 6 & 1,149 & 6 & .32 to .71 & .58 & .59 & $.68^{* * *}$ & .02 & .65 & .71 & $59 * * *$ & $9 \%$ & 75 \\
\hline \multicolumn{14}{|l|}{ Customer Consequences } \\
\hline Customer Orientation $(\alpha=.80)$ & 7 & 1,743 & 7 & .07 to .57 & .29 & .29 & $.34 * * *$ & .02 & .30 & .38 & $22 * * *$ & $29 \%$ & 40 \\
\hline \multicolumn{14}{|l|}{ Innovation Consequences } \\
\hline Innovation $(\alpha=.83)$ & 7 & 1,879 & 7 & .09 to .48 & .33 & .37 & $.43 * * *$ & .02 & .40 & .47 & $30 * * *$ & $16 \%$ & 53 \\
\hline Market Innovation Capacity $(\alpha=.74)$ & 3 & 888 & 3 & .23 to .34 & .27 & .28 & $.34 * * *$ & .03 & .28 & .40 & 4 & $29.3 \%$ & 17 \\
\hline New Product Performance $(\alpha=.81)$ & 2 & 501 & 2 & .19 to .32 & .25 & .29 & $.31^{*}$ & .04 & .21 & .37 & $4^{*}$ & $13 \%$ & $\mathrm{NC}$ \\
\hline \multicolumn{14}{|l|}{ Organizational Performance } \\
\hline Profit $(\alpha=.91)$ & 10 & 1,385 & 11 & -.32 to .44 & .18 & .20 & $.24 * * *$ & .02 & .19 & .29 & $32 * * *$ & $24 \%$ & 41 \\
\hline Sales $(\alpha=.92)$ & 9 & 1,086 & 10 & -.10 to .68 & .15 & .12 & $.14 * * *$ & .03 & .08 & .20 & $37 * * *$ & $19 \%$ & 18 \\
\hline Sales by Employee $(\alpha=.91)$ & 2 & 223 & 2 & .34 to .70 & .52 & .37 & $.39 * * *$ & .06 & .27 & .50 & $11 * * *$ & $9 \%$ & $\mathrm{NC}$ \\
\hline Market Share $(\alpha=.75)$ & 4 & 942 & 4 & .16 to .44 & .29 & .32 & $.41 * * *$ & .03 & .36 & .46 & $38 * * *$ & $7 \%$ & 28 \\
\hline Objective Performance $(\alpha=1.00)$ & 5 & 404 & 6 & -.03 to .73 & .32 & .37 & $.38^{* * *}$ & .05 & .30 & .47 & $41 * * *$ & $11 \%$ & 39 \\
\hline Subjective Performance $(\alpha=.90)$ & 13 & 3,587 & 16 & -.06 to .52 & .29 & .40 & $.26 * * *$ & .02 & .23 & .29 & $72 * * *$ & $19 \%$ & 67 \\
\hline \multicolumn{14}{|l|}{ Additional Analysis } \\
\hline Global Performance Index $(\alpha=.86)$ & 22 & 4,537 & 26 & -.32 to .73 & .52 & .37 & $.39 * * *$ & .06 & .27 & .50 & $11 * * *$ & $9 \%$ & 176 \\
\hline
\end{tabular}

Note:: $* p<.05 ; * * p<.01 ; * * *<<.001 ; K=$ number of studies; $N=$ Combined $N$ over all independent cumulative samples size; $O=$ Number of observations; Range $=$ Minimum and Maximum value for $r$; Effect Size $=$ is the corrected mean correlation coefficients by both the sample-size-weighted and reliability-corrected estimates; SE $=$ Standard Error of Effect Size $(1 /{ }[N-3]) ; \mathrm{L}_{\mathrm{CI}}=$ Lower confidence interval (Homo); $\mathrm{U}_{\mathrm{CI}}=$ Upper confidence interval (Homo); $Q=$ Statistic for Homogeneity at Individual Level $\left(Q=\Sigma_{w i} E S_{i}^{2}-\left(\Sigma_{w i} E S_{i}\right)^{2} / \Sigma_{w i}\right) ; \%$ Acc. $=$ Indicates how much variance is due to sampling error; File Drawer $=$ (availability bias) refers to the number of unpublished studies reporting the null results needed to reduce the cumulative effect across studies to the point of non-significance (Hunter \& Schmidt, 2004); $\mathrm{NC}=$ no calculated since $O \leq 2$; Global Market Orientation reliability $\alpha=.86$. 
The outcomes also showed that the interdepartmental environment $(r=.53 ; p<.05)$, which is the organizational atmosphere, had a positive impact on market orientation (see measures in Gonçalves et al., 2002; Slongo \& Bossardi, 2004).

The rules for the job execution construct also had a significant positive relationship with market orientation $(r=.40 ; p<.000)$. Rules for job execution mean the degree of formalization (Gonçalves et al., 2002), burocracy (Costa, 2006), control in executing the work (Dalmoro \& Faleiro, 2007) and roles for doing the job (Révillion, 2005). The rules for the job execution construct have to do with the definition of roles, procedures and authority through rules.

The $Q$-test for homogeneity was not significant in the rules for job execution-market orientation association, rejecting the heterogeneity evidence $(6 ; p=\mathrm{NS})$. Heterogeneity estimates greater than zero can indicate the presence of real heterogeneity or can be a result of sampling fluctuations. Therefore, a significant $Q$-test result suggests that the calculated effect size is not applicable to the entire group. Monte Carlo simulations showed that the $Q$-test keeps the tightest control of the Type I error rate (when compared with the Likelihood Ratio and Wald's Estimation), although the results emphasize the importance of large sample sizes within the set of studies (Viechtbauer, 2007).

Consequences of Market Orientation. Market orientation had a heavy impact on organizational commitment $(r=.78 ; p<.05)$. We used for commitment Dalmoro and Faleiro's (2007) and Faleiro's (2001) studies. Market orientation also had an impact on organizational learning ( $r=.68 ; p<.000)$. The literature considers that organizational learning, one of the most important consequences of market orientation, represents the company's capacity to move from one given position to another, suggesting that the influence of market orientation on performance is significant when it is mediated by organizational learning (Jiménez-Jiménez \& Cegarra-Navarro, 2007). A cyclic relationship is suggested here, where the greater the market philosophy, the greater firms' knowledge in comprehending the market, which, by this wisdom, should improve the marketplace focus. To complement, some papers that have measured learning include Gonçalves et al. (2002), Perin (2002), Perin et al. (2002), Perin et al. (2006), Perin et al. (2005) and Costa (2006).

Market orientation also predicted customer orientation $(r=.34 ; p<.000)$. The explanation for that weakness could be due to the biased use of the MARKOR scale in Brazilian papers (Kohli, Jaworski, \& Kumar, 1993). The MARKOR scale focuses more on the market than on clients, influencing the results. Some papers that measured consumer orientation were Gonçalves et al. (2002), Santos and Rossi (2005), Sampaio (2000), Souza (2004), Perin et al. (2006), Révillion (2005), Souza (2004) and Costa (2006). The MARKOR scale uses the following dimensions: generation of information, dissemination of information and responsiveness of the disseminated information.

Market orientation influenced innovation $(r=.43 ; p<.000)$, market innovation capacity $(r=.34$; $p<.000)$ and new product performance $(r=.31 ; p<.05)$. As a result, hypotheses $\mathrm{H}_{4}, \mathrm{H}_{5 \mathrm{a}}, \mathrm{H}_{5 \mathrm{~b}}$ and $\mathrm{H}_{5 \mathrm{c}}$ are supported.

The articles that measured innovation were Müller Neto (2005), Gonçalves et al. (2002), Costa (2006), Perin and Sampaio (2003), Faleiro (2001), Perin et al. (2002) and Galão et al. (2007); those that measured new product performance were Perin et al. (2005) and Perin et al. (2006); and those that measured market innovation capacity were Perin et al. (2005), Perin et al. (2006) and Gonçalves et al. (2002).

Business Performance. Performance was measured by profit, sales, sales by employee and market share. The significant association between market orientation and profit was significant $(r=.24$; $p<.000)$. On the other hand, the market orientation-sales by employee link comprehends the individual employee focus on sales, attendance and politeness. According to the data, this hypothesis was supported $(r=.39 ; p<.000)$. The association between market orientation and market share was the strongest of the Brazilian scientific data $(r=.41 ; p<.000)$. File-drawer means that just five non significant and/or unavailable Brazilian studies investigating this relationship are necessary to bring the cumulated market share effect size to a non significant value. 
The market orientation-sales link is the weakest correlation found $(r=.14 ; p<.000)$, which may be due to the large correlation variation -.10 to .68 and to the large sample size reporting non significant effects. For instance, non significant results (22\%) were found by Müller Neto (2005), $r=-.05 ; p=\mathrm{NS}$; $N=781$, and by Perin et al. (2005), $r=.02 ; p=\mathrm{NS} ; N=208$. On the other hand, weaker associations (44\% below $r$.14) were found by Perin et al. (2006), $r=.13 ; p<.05 ; N=293$, by Mandelli (1998), $r=$ $.14 ; p<.05 ; N=29$, and by Silva et al. (2002), $r=.13 ; p<.05 ; N=43$. Based on these examples, the weak result could be due to the fact that correlations from large samples, listed above, are near to the population average, as proposed by the Central Limit Theorem Theory (Hunter \& Schmidt, 2004). If this assumption is correct, a low or non significant association between market orientation and sales can be assumed, as illustrated by the papers. Note that the market orientation-sales link correlation corrected just by sample size presented an effect size of $r=.12(p<.01)$. In comparison, Kirca et al. (2005) suggested that market orientation-performance link $(r=.46 ; p<.05)$ was the strongest in their study. In this circumstance, the four studies used as market share were positive and significant, although the file-drawer was low.

The objective and subjective performance measures were positively associated with market orientation $(r=.38 ; p<.000$ and $r=.26 ; p<.000)$. Furthermore, a global effect size was created to represent the performance measure. We use the average of all the objective and subjective performance measures to create a universal indicator. The sample accumulated in this global effect size was 4,537 (22 papers); with just $9 \%$ of variance due to sampling error. The correlation between market orientation and global performance was strong $(r=.39 ; p<.001)$. The findings are consistent with the predominant expectations in prior research (Kohli \& Jaworski, 1990, 1993; Narver \& Slater, 1990, 1995; Shoham et al., 2005). It is important to comment that other variables are as important as market orientation in explaining performance, since the $r^{2}$ was just $15 \%$. Figure 2 shows the results.

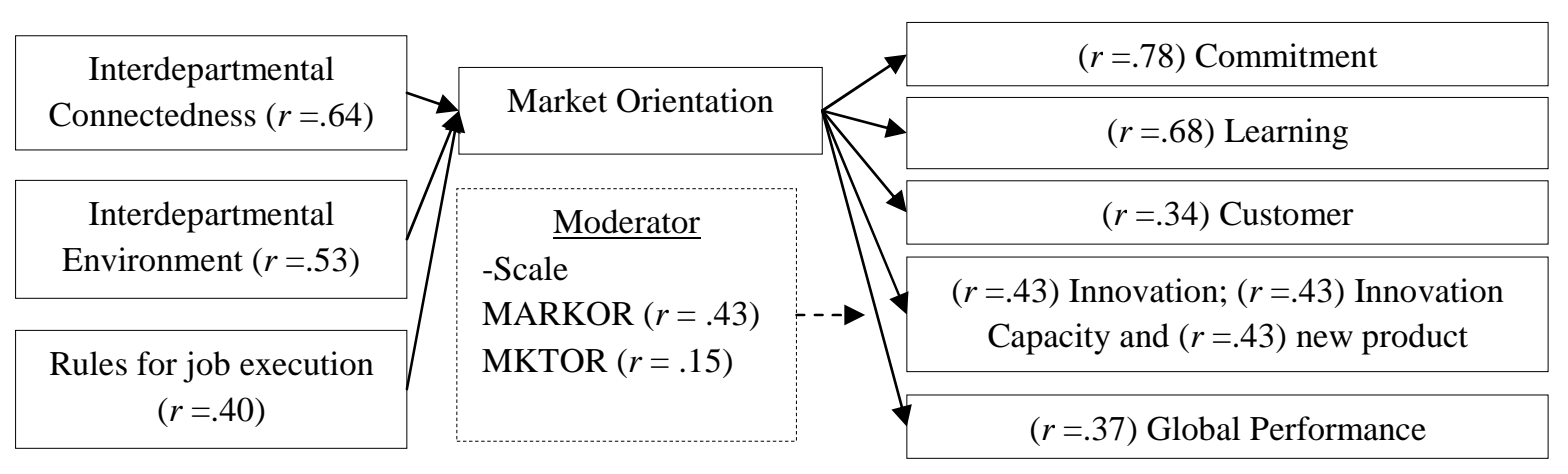

Figure 2: Antecedents and Consequences of Market Orientation: Main Results Note: correlations are all significant at $p<.01$; moderator is significant at $p<.07$.

Hypothesized Moderators. This topic analyzes the moderators that affect the market orientationperformance association. This paper does not test costs involved in implementing a strategy vs. measures that emphasize revenues as moderator, since from the 22 studies that measured performance, all of them used some kind of revenue-based performance. Other moderator hypotheses were tested using regression analysis, in which the effect size coefficient between two variables was entered as an endogenous variable, the factors were entered as exogenous variables (i.e. dummy variables), and reliability was used as a covariate. Alpha coefficients for $y$ and $x$ did not show significance. The moderator variables were objective (frequency [“f”] $=7) v$ s. subjective measures $(f=19)$; multi-item $(f$ $=21) v s$. single-item measure $(f=5)$; manufacturing $(f=10) v s$. service industry $(f=16)$ and measurement MARKOR $(f=16) v s$. MKTOR scales $(f=6)$.

Objective vs. Subjective Measures. Business performance has been investigated by both subjective (e.g. self-reported) and objective measures (e.g. ROI, market share, sales). The discrepancy between objective and subjective scales has been recognized and discussed in market orientation literature (Cano et al., 2004). According to Harris (2001), the strength of the relationship between market 
orientation and organizational performance using subjective evaluations might differ from relationship tests using objective measures. In this condition, common methods variance may strengthen the correlation between market orientation and performance when research uses a subjective measure (Doty \& Glick, 1998). Dawes (1999) also presents the danger of obtaining a false positive result (i.e. Type I Error) when using subjective rather than objective measures of business performance. Consequently, subjective measures of business performance may cause the correlation coefficient to be artificially inflated. This hypothesis was supported by Kirca et al. (2005) and discarded by Cano et $a l$. (2004) and by this paper $(\beta=.04 ; p>.86)$, rejecting the assumption.

Multi vs. Single-Item Measures. Henard and Szymanski (2001) believe that the use of multi-item measures of performance should be associated with higher market orientation-performance correlations than the use of single-item measure, because multi-item measures are more capable of capturing various facets of complex constructs. This study rejected that assumption $(\beta=.02 ; p>.94)$.

Manufacturing vs. Service Industry. For Gray and Hooley (2002) there is equivocal evidence of the moderating effect of industry type (service $v s$. manufacturing) on the relationship between market orientation and business performance. The implementation of market orientation could entail a higher degree of customization in services firms than in manufacturing firms, which implies that the correlation between these two constructs might vary (Cano et al., 2004). Moreover, this association should be greater in service firms due to greater dependence on person-to-person interaction, which has more customer communication and personalized services than those of manufacturing firms (Kirca et al., 2005). In this article, the result did not have significance $(\beta=-.17 ; p>.43)$, rejecting the assumption.

MARKOR vs. MKTOR Measurement. Research indicates that although both scales are theoretically consistent, in general the MKTOR outperforms the MARKOR when it comes to explaining business performance variance (Oczkowski \& Farrell, 1998). The MKTOR scale comprises three core elements: customer orientation, competitor orientation, and interfunctional coordination. On the other hand, the MARKOR scale has three components: generation of market information; dissemination of information and responsiveness capacity. According to Narver and Slater (1990), the MKTOR associates stronger with business performance than the MARKOR because it fully captures the notion of providing customer value and superior business performance.

Data suggested that the relationship between market orientation and performance is stronger when measured by the MARKOR scale, supporting the assumption $\left(\beta=.40 ; p<.07 ; \mathrm{R}^{2} \mathrm{Adj}=.11\right.$; Max Variance Inflation Factor $=1.00$ ). This finding could be a consequence of the extensive use of the MARKOR scale in Brazil, indicating that it could be more adapted to our business field. Of the 22 papers analyzed, $72 \%$ (16) used the MARKOR scale. Cano et al. (2004) also found that the MARKOR measurement influences the relationship between market orientation and business performance. On the other hand Kirca et al. (2005) and Shoham et al. (2006) did not support the MARKOR scale moderator hypothesis.

When an isolated analysis was done, the effect size for market orientation-performance link was stronger in the MARKOR sample $\left(t(21)=-1.89 ; r_{\text {MARKOR }}=.43 v s . r_{\text {MKTOR }}=.15 ; p<.073 ; N=2.495\right)$, when compared to the MKTOR sample $(N=1,094)$. According to Cano et al. $(2004)$, the MARKOR $r=$ ${ }_{.42}$ scale also produced stronger correlations than the MKTOR $r=.28$.

\section{STUDY 2: INTERNATIONAL MEGA-ANALYSIS}

What is the mean impact of international market orientation on its consequences using megaanalysis? Aiming to answer this question, this paper does a mega-analysis on seven international metaanalyses, prepared especially for market orientation, seeking to provide insights into inconsistencies by accumulating effects across global studies. In that sense, the mega-analysis contributes to international marketing by adjusting the global effect sizes, comparing the international results and 
evaluating the main performance predictor. The literature uses mega-analysis to summarize the different published meta-analyses.

Methodology. These variables helped created the mega-analysis database because it only sought other meta-analytic studies in market orientation. The seven international meta-analyses specific to market orientation are: Cano et al. (2004), Ellis (2006), Grinstein (2008), Kirca et al. (2005), Krasnikov and Jayachandran (2008), Shoham et al. (2005) and this study [this].

International Mega-Analysis Findings. Table 2 presents the descriptive results from the seven international meta-analyses on market orientation. The dependent variables were performance, innovation, learning and commitment. We can see from the market orientation-performance link that the simple average of the effect size for these papers was $r_{\text {mean }}=.32$, accounting on average for $10 \%$ of the business performance. Market orientation-performance $N$ accumulated was $120,246\left(M_{\text {mean }}=\right.$ 17,178). The association between market orientation and innovation presented by Kirca et al. (2005) was the strongest in the data base $(r=.45)$ and near to the global average $r_{\text {mean }}=.43$. Market orientation also had a positive impact on learning and commitment, $r_{\text {mean }}=.65$ and $r_{\text {mean }}=.67$, respectively.

Table 2

Effect Sizes from Market Orientation to (...)

\begin{tabular}{|c|c|c|c|c|c|c|c|c|c|c|c|c|}
\hline Study & Perf. & $N$ & $r^{2}$ & Innov & $N$ & $r^{2}$ & Lear. & $N$ & $r^{2}$ & Com. & $N$ & $r^{2}$ \\
\hline CCJ (2004) & .35 & 12,043 & $12 \%$ & & & & & & & & & \\
\hline KJ (2008) & .35 & 19,176 & $12 \%$ & & & & & & & & & \\
\hline $\begin{array}{l}S \text { et al } \\
(2006)\end{array}$ & .33 & 1,589 & $18 \%$ & & & & & & & & & \\
\hline E (2006) & .26 & 14,586 & $7 \%$ & & & & & & & & & \\
\hline SRK (2006) & .28 & 5,165 & $8 \%$ & & & & & & & .51 & 1,235 & $26 \%$ \\
\hline KJB (2005) & .32 & 63,150 & $10 \%$ & .45 & 6,013 & $20 \%$ & & & & .71 & 2,203 & $50 \%$ \\
\hline This paper & .39 & 4,537 & $15 \%$ & .43 & 1,879 & $18 \%$ & .68 & 1,149 & $46 \%$ & .78 & 1,48 & $61 \%$ \\
\hline G (2008) & & & & .40 & 10,496 & $16 \%$ & .63 & 3,174 & $40 \%$ & & & \\
\hline $\begin{array}{l}\text { Simple } \\
\text { Mean }\end{array}$ & .32 & 17,178 & $10 \%$ & .43 & 6,129 & $18 \%$ & .65 & 2,161 & $43 \%$ & .67 & 1,195 & $45 \%$ \\
\hline
\end{tabular}

Note. blank = not available; $N=$ sample size accumulated; Perf. = Performance; Innov. = Innovation; Lear = Learning; Com. = Commitment; Market orientation-performance $N$ accumulated 120,246; Market orientation-innovation $N$ accumulated 18,338; Market orientation-learning $N$ accumulated 4,323; Market orientation-commitment $N$ accumulated 3,586.

According to the data, market orientation was positively associated with performance $\left(r_{\text {mega-analysis }}=\right.$ $.33 ; p<.000)$. The range value of market orientation, $r$, was from $.26_{\text {minimum }}$ to $39_{\text {maximum }}$. Note that the $r$ $=.33$ mega-analysis effect size was near to the effect sizes (see Table 2) found by the other seven investigations (e.g. Cano et al., 2004; Ellis, 2006; Grinstein, 2008; Kirca et al., 2005; Krasnikov \& Jayachandran, 2008; Shoham et al., 2005 and this paper) and that these values had little variance across studies $(\sigma=.001 ; \mathrm{SD}=.02)$.

The mega-analysis also found that market orientation was associated with innovation $(r=.42$; $p<.000)$, learning $(r=.64 ; p<.000)$, and commitment $(r=.64 ; p<.000)$, suggesting that the latter two constructs received the greatest impact from market orientation $\left(r^{2}=41 \%\right)$. The mega-analysis accumulated effect sizes across seven international meta-analyses, supporting the notion that the impact of market philosophy on business performance does not have variation across countries. This 
result is also supported by Cano et al. (2004), who found that market orientation-performance association does not have variation across countries, gross domestic product per capita [GDP] and the United Nations Human Development Index [HDI].

Table 3

International Mega-Analysis of Market Orientation

\begin{tabular}{lrrrrrrrrrrrrr}
\hline \multicolumn{1}{c}{$\begin{array}{c}\text { Construct } \\
\text { Hypothesis }\end{array}$} & $\boldsymbol{K}$ & $\boldsymbol{N}$ & $\boldsymbol{O}$ & Range & $\boldsymbol{r}_{\mathrm{si}}$ & $\boldsymbol{r}_{\mathrm{sa}}$ & $\mathbf{E S}$ & $\mathbf{S}$ & $\mathbf{L}_{\mathrm{CI}}$ & $\mathbf{U}_{\mathrm{CI}}$ & $\boldsymbol{Q}$ & $\begin{array}{c}\% \\
\text { Acc }\end{array}$ & $\begin{array}{c}\text { File } \\
\text { Drawer }\end{array}$ \\
\hline $\begin{array}{l}\text { International } \\
\text { Mega-analysis }\end{array}$ & & & & & & & & & & & & & \\
& & & & & & & & & & & & & \\
MO-Performance & 7 & 120,246 & 7 & .26 to .39 & .32 & .33 & .33 & .00 & .32 & .33 & 137 & 0 & 37 \\
MO-Innovation & 3 & 18,358 & 3 & .40 to .45 & .42 & .43 & .42 & .00 & .41 & .43 & 14 & 10 & 22 \\
MO- Learning & 2 & 4,323 & 2 & .63 to .68 & .64 & .65 & .64 & .00 & .63 & .66 & 6 & 9 & 23 \\
MO-Commitment & 3 & 3,586 & 3 & .51 to .78 & .64 & .67 & .64 & .00 & .62 & .66 & 93 & 2 & 35 \\
\hline
\end{tabular}

Note. $\mathrm{MO}=$ Market Orientation; $K=$ number of studies; $N=$ Combined $N$ over all independent cumulative samples size; $O=$ Number of observations; Range $=$ Minimum and Maximum value for $r ; r_{\mathrm{si}}=$ simple mean; $r_{\mathrm{sa}}=$ adjusted by sample; Effect Size $_{\mathrm{ES}}($ all $p<.001)=$ is the corrected mean correlation coefficients by both the sample-size-weighted and reliabilitycorrected estimates; $\mathrm{SE}_{\mathrm{S}}=$ Standard Error of Effect Size $(1 / \sqrt{ }[N-3]) ; \mathrm{L}_{\mathrm{CI}}=$ Lower confidence interval $($ Homo $)$; $\mathrm{U}_{\mathrm{CI}}=\mathrm{Upper}$ confidence interval (Homo); $Q=$ Statistic for Homogeneity at Individual Level $\left(Q=\Sigma_{w i} E S_{i}^{2}-\left(\Sigma_{w i} E S_{i}\right)^{2 /} \Sigma_{w i}\right), \mathrm{Q}=$ all $p<.05$; $\%$ Acc. $=$ Indicates how much variance is due to sampling error; File Drawer $=$ (availability bias) refers to the number of unpublished studies reporting the null results needed to reduce the cumulative effect across studies to the point of nonsignificance (Hunter \& Schmidt, 2004)

Mega-Analysis Moderator. According to Table 4, measurement influences the relationship between market orientation and business performance. Data indicated that the market orientationperformance link is stronger when market orientation is measured using the MARKOR rather than the MKTOR scale (Cano et al., 2004; This paper; Ellis, 2006). As hypothesized, the relationship between market orientation and business performance is stronger when the subjective scale rather than the objective scale is used to measure business performance (Cano et al., 2004; Ellis, 2006; Kirca et al., 2005; Krasnikov \& Jayachandran, 2008). These two results mean that international literature converges to support the moderator aspect of the relationship tested. Table 4 shows other nonsignificant moderators.

Table 4

Moderators that Affect Market Orientation-Performance Relationship According to MetaAnalyses

\begin{tabular}{ll}
\hline Non-Significant $(\boldsymbol{p}=\mathrm{NS})$ & Significant Moderator $(\boldsymbol{p}<.05)$ \\
\hline KJB (2005): Cost based $v s$. revenue based & KJB (2005): Manufacturing $>$ Services segment \\
KJB (2005): Single $v s$. multi item scale & KJB (2005): Low uncertainly $>$ high uncertainly cultures \\
This: Single $v s$. multi item scale & KJB (2005): Low power distance $>$ high power distance \\
KJB (2005): MARKOR $v s$. MKTOR & \\
\hline
\end{tabular}


Table 4 (continued)

KJB (2005): Date of publication

KJB (2005): Individualism vs. collectivism

KJB (2005): Masculinity vs. femininity

CCJ (2004): Individualism vs. collectivism

CCJ (2004): GDP

CCJ (2004): HDI

This: Subjective vs. Objective measure

This: Manufacturing vs. Services Industry

KJ (2008): Large vs. small firms

KJ (2008): B2B vs. B2C

KJ (2008): Manufacturing vs. Services Industry

KJ (2008): USA vs. non-USA investigation

KJ (2008): Multiple vs. Single Industry

E (2006): Business vs. Market Level
CCJ (2004): Note for profit > profit firms

CCJ (2004): Services > manufacturing segment

E (2006): West $>$ East hemisphere

E (2006): Large > Small Market

E (2006): Mature > Developing Economies

\section{MARKOR > MKTOR}

Support by CCJ (2004); This; E (2006)

.42 vs .28; 42. vs .15; .32 vs .25; respectivelly

Subjective $>$ Objective measure

Supported by KJB (2005); CCJ (2004): KJ (2008); E (2006):

NA; respectively; .41 vs .29; NA; .27 vs .22; respectivelly

Note. A > B means that Condition $_{\mathrm{A}}$ introduces a stronger relationship when compared to Condition ${ }_{\mathrm{B}}$; NA = Not available.

\section{MARKETING CONTRIBUTION}

For managerial decisions, the outcomes presented here highlight the importance of interdepartmental connectedness in order to be market oriented. Interdepartmental connectedness is defined as the degree of formal and informal direct contact among employees across departments (Kohli \& Jaworski, 1990). Related literature suggests that interdepartmental connectedness facilitates the exchange and use of information across organizational boundaries (Deshpandé \& Zaltman, 1982). In addition, there are other examples suggesting that informal networks rather than formal organization structures are increasingly affecting organizational activities, use of information and outcomes (Menon, Bharadwaj, Adidam, \& Edison, 1999).

Secondly, market orientation has a strong impact on organizational learning. Slater and Narver (1995) concluded that market orientation is only likely to significantly enhance performance when it is combined with a strong learning orientation. That point is presented here, where learning is combined with market orientation to influence performance.

Thirdly, as important as market orientation and interdepartmental connectedness are, they must be complemented by an appropriate organizational atmosphere to produce a learning organization (Slater \& Narver, 1995). One example of organizational learning is working together with clients - in a coproduction style or a co-creator (Vargo \& Lusch, 2004). In fact, the customer orientation concept reliance on either only customer-focused or competitor-focused decision making can often lead to an incomplete business strategy, leaving an organization handicapped by a reactive posture (Day \& Wensley, 1988).

In addition, market orientation through intelligence generation is a source of ideas for new products and services, which, together with the focus on providing superior value to the customers by means of fulfilling their needs and the evolution of their preferences, should positively affect the degree of innovation in companies (Vazquez, Santos, \& Alvarez, 2001). In this study, market orientation explained a large amount of variation on firms' innovation. 
Fourthly, the ten studies included in this meta-analysis supported the assumption that market orientation has a strong impact on profit. In parallel, the studies also confirmed the market orientationmarket share link. Note that these are two important measures of objective performance supporting the managers' use of marketing strategy philosophy. To complement, there is a positive and significant correlation between global market orientation and performance (supporting previous research by Deshpandé \& Farley, 1998; Slater \& Narver, 1994a).

In short, this study extends prior attempts to understand the market orientation-performance association by employing a considerable number of effect sizes and other relationships. The data base was the Brazilian papers, which represent a scientific effort to apply international theory to practical management. The results found here have not only supported the international literature on this topic, but also shown the Brazilian industry focus on its market and customers. Thus, the findings indicate the managers' maturity in terms of understanding domestic markets, anticipating competitors' moves, finding new opportunities and discovering what customers need.

\section{General Conclusions}

For academics, the main conclusion found here is that independent of the measure, objective $v s$. subjective, and independent of the indicator used (i.e. sales, profit, market-share, etc.), the country's economy, the GDP or HDI, the culture (individualistic vs. collectivistic), the industry (B2B vs. B2C), etc., market orientation has a significant and positive impact on performance across countries. The effect size is positive and, when compared to other meta-analyses, is positioned in the top three performance predictors. From the evidence, it is now necessary to discover other consequences and potential moderators to bring noteworthy results to international marketing theory. Articles investigating just the market orientation-performance association might not achieve a real scientific contribution for the international community, since this mega-analysis summarized the international results and presents a solid conclusion. Therefore, the market orientation-performance link is no longer a global uncertainty.

For managers, at first glance, the results discussed here imply a more market-oriented view within the organization. Sometimes the exacerbated focus on market, industry, economy, international market and competitors jeopardizes firms' performance and capacity for innovation (Narver, Slater, \& MacLachlan, 2004). In fact, firms' environment and interdepartmental connectedness improve the way that multinationals view the movement of markets beyond their windows. To be market oriented is necessary in order to generate and distribute the concept within organizations, incorporating multiple systems of belief and developing a more complex corporate culture. The significance of the three antecedents confirms this assumption, showing that market orientation is related to a number of strategic orientations (i.e. environment). Next, the results of the market orientation dissemination will appear not only on a better performance, but also on organizational commitment, innovation and learning. As a result, the use of market orientation strategy might permit organizations to discover or to anticipate incessantly what consumers need, to learn from them in a coproduction and to be able fulfill those needs with new solutions and customized products.

\section{ACKNOWLEDGEMENTS}

The author would like to thank Andre T. Urdan, Claudio Damacena, Claudio H. Sampaio, Cid Gonçalves, Marcelo G. Perin, and Marlon Dalmoro, for sending their data base. The author would also like to thank Alexandre Faria, Elizandra Severgnini, Francisco G. D. Vieira and the anonymous reviewers for their comments on previous versions of this article. 


\section{REFERENCES}

Antoni, L. V. (2004). A relação entre orientação para o mercado e performance organizacional: um estudo nos cursos de bacharelado em administração da região sul do Brasil. Doctoral dissertation, Universidade Federal de Santa Catarina, Florianópolis, SC, Brazil.

Barney, J. (1991). Firm resources and sustained competitive advantage. Journal of Management, 17(1), 99-120.

Bhuian, S. N. (1997). Exploring market orientation in banks: an empirical examination in Saudi Arabia. Journal of Services Marketing, 11(5), 317-328.

Brown, S. P., \& Peterson, R. A. (1993). Antecedents and consequences of salesperson job satisfaction: meta-analysis and assessment of causal effects. Journal of Marketing Research, 30(1), 63-77.

Cano, C. R., Carrillat, F. A., \& Jaramillo, F. (2004). A meta-analysis of the relationship between market orientation and business performance: evidence from five continents. International Journal of Research in Marketing, 21(3), 179-200.

Carvalho, G. G. (2001). A orientação para o mercado e a performance dos negócios na rede de distribuidores de veículos Fiat nos estados do Rio Grande do Sul e Santa Catarina. Mestrado Interinstitucional. Masters dissertation, Universidade Federal do Rio Grande do Sul, Porto Alegre, RS, Brazil.

Costa, L. S. V. (2006). O coalinhamento entre as estratégias competitivas e colaborativas como forma de influenciar o ambiente e melhorar o desempenho de empresas. Doctoral dissertation, Pontifícia Universidade Católica, Rio de Janeiro, RJ, Brazil.

Dalmoro, M., \& Faleiro, S. N. (2007, May). As atitudes e percepções da gerência como influenciadores da performance exportadora e orientação para mercado externo. Proceedings of the Encontro de Estudos em Estratégia, São Paulo, SP, Brazil, 3.

Damanpour, F. (1991). Organizational innovation: a meta-analysis of effects of determinants and moderators. Academy of Management Journal, 34(3), 555-590.

Dawes, J. (1999). Market orientation and company profitability: further evidence incorporating longitudinal data. Australian Journal of Management, 25(2), 173-199.

Day, G. S., \& Wensley, R. (1988). Assessing advantage: a framework for diagnosing competitive superiority. Journal of Marketing, 52(2), 1-20.

Deshpandé, R., \& Farley, J. U. (1998). Measuring market orientation: generalization and synthesis. Journal of Market Focused Management, 2(3), 213-198.

Deshpandé, R., Farley, J. U., \& Webster, F. E., Jr. (1997). Factors affecting organizational performance: a five-country comparison [Working Papers $\mathrm{N}^{\circ}$ 97-108]. Marketing Science Institute, Cambridge, MA, USA.

Deshpandé, R., \& Zaltman, G. (1982). Factors affecting the use of market research information: a path analysis. Journal of Marketing Research, 19(1), 14-31.

Doty, H. D., \& Glick, W. H. (1998). Common method bias: does common methods variance really bias results? Organizational Research Methods, 1(4), 374-406.

Ellis, P. D. (2006). Market orientation and performance: a meta-analysis and cross national comparisons. Journal of Management Studies, 43(5), 1089-1097. 
Faleiro, S. N. (2001). A relação entre orientação para o mercado, orientação para a aprendizagem e inovação, o caso dos cursos de graduação em administração filiados à Angrad. Masters dissertation, Universidade Federal do Rio Grande do Sul, Porto Alegre, RS, Brazil.

Farrell, M. A. (2000). Developing a market-oriented learning organization. Australian Journal of Management, 25(2), 210-222.

Galão, F. P., Pacagnan, M. N., Silva, V. A., \& Frutos, F. P. P. (2007, September). A relação da orientação para o mercado e o comportamento inovador das indústrias do vestuário. Proceedings of the Seminários em Administração, São Paulo, SP, Brazil, 9.

Gava, R., \& Silveira, T. (2007). A orientação para o mercado sob a ótica da empresa e dos clientes na indústria hoteleira gaúcha. Revista de Administração Contemporânea, 11(2), 49-69.

Gonçalves, C., Filho, Gonçalves, C. A., \& Veiga, R. T. (2002, September). Orientação ao mercado, gestão do conhecimento de marketing e o sucesso de novos produtos: uma pesquisa empírica no setor industrial. Proceedings of the Encontro Nacional da Associação Nacional de PósGraduação e Pesquisa em Administração, Salvador, BA, Brazil, 26.

Gray, B. J., \& Hooley, G. J. (2002). Market orientation and service firms performance - a research agenda. European Journal of Marketing, 36(9/10), 980-800.

Grinstein, A. (2008). The relationships between market orientation and alternative strategic orientations: a meta-analysis. European Journal of Marketing, 42(1/2) 115-134.

Han, J. K., Kim, N., \& Srivastava, R. K. (1998). Market orientation and organizational performance: is innovation a missing link? Journal of Marketing, 62(4), 30-45.

Harris, L. C. (2001). Market orientation and performance: objective and subjective empirical evidence from UK companies. Journal of Management Studies, 38(1), 17-43.

Henard, D. H., \& Szymanski, D. M. (2001). Why some new products are more successful than other. Journal of Marketing Research, 38(3), 362-375.

Homburg, C., \& Pflesser, C. (2000). A multiple-layer model of market-oriented organizational culture: measurement issues and performance outcomes. Journal of Marketing Research, 37(4), 449-462.

Hooley, G., Cox, T., Fahy, J., Shipley, D., Beracs, J., Fonfara, K., \& Snoj, B. (2000). Market orientation in the transition economies of central Europe: tests of the narver and slater market orientation scales. Journal of Business Research, 50(3), 273-285.

Hult, T. G., \& Ketchen, D. J. (2001). Does market orientation matter? A test of the relationship between positional advantage and performance. Strategic Management Journal, 22(9), 899-906.

Hunter, J. E., \& Schmidt, F. L. (2004). Methods of meta-analysis: correcting error and bias in research findings (2nd ed.). Beverly Hills, CA: Sage.

Hurley, R. F., \& Hult, G. T. (1998). Innovation, market orientation and organizational learning: an integration and empirical examination. Journal of Marketing, 62(3), 42-54.

Im, S., \& Workman, J. P. (2004). Market orientation, creativity and new product performance in hightechnology firms. Journal of Marketing, 68(2), 114-132.

Jaworski, B., \& Kohli, A. K. (1993). Market orientation: antecedents and consequences. Journal of Marketing, 57(3), 53-70.

Jaworski, B., \& Kohli, A. K. (1996). Market orientation: review, refinement and roadmap. Journal of Market-Focused Management, 1(2), 119-153. 
Jiménez-Jiménez, D., \& Cegarra-Navarro, J. G. (2007). The performance effect of organizational learning and market orientation. Industrial Marketing Management, 36(6), 694-709.

Kennedy, K., Goolsby, J. R., \& Arnould, E. J. (2003). Implementing a customer orientation: extension of theory and applications. Journal of Marketing, 67(4), 67-81.

Kirca, A. H., Jayachandran, S., \& Bearden, W. (2005). Market orientation: a meta-analytic review and assessment of its antecedents and impact on performance. Journal of Marketing, 69(2), 24-41.

Kohli, A. K., \& Jaworski, B. J. (1990). Market orientation: the construct, research propositions and managerial implications. Journal of Marketing, 54(2), 1-18.

Kohli, A. K., \& Jaworski, B. J. (1993). Market orientation: antecedents and consequences. Journal of Marketing, 57(3) 53-70.

Kohli, A. K., Jaworski, B., \& Kumar, B. (1993). MARKOR: a measure of market orientation. Journal of Marketing Research, 30(2), 467-771.

Krasnikov, A., \& Jayachandran, S. (2008). The relative impact of marketing research-anddevelopment, and firm operations capabilities on firm performance. Journal of Marketing, $72(3), 1-11$.

Mandelli, M. (1998). Orientação para o mercado e o crescimento de vendas: um estudo nas maiores empresas privadas industriais metalúrgicas, mecânicas e de material elétrico de Caxias do Sul. Masters dissertation, Universidade Federal do Rio Grande do Sul, Porto Alegre, RS, Brazil.

Menna, H. L. (2001, September). Orientação para mercado e performance: evidências em empresas Gaúchas de varejo de confecções masculinas. Proceedings of the Encontro Nacional da Associação Nacional de Pós-Graduação e Pesquisa em Administração, Campinas, SP, Brazil, 25.

Menon, A., Bharadwaj, S. G., Adidam, P. T., \& Edison, S. W. (1999). Antecedents and consequences of marketing strategy making: a model and a test. Journal of Marketing, 63(2), 18-40.

Narver, J. C., \& Slater, S. F. (1990). The effect of a market orientation on business profitability. Journal of Marketing, 54(4), 20-35.

Narver, J. C., \& Slater, S. F. (1995). Market orientation and the learning organization. Journal of Marketing, 59(3), 63-74.

Narver, J. C., Slater, S. F., \& MacLachlan, D. (2004). Responsive and proactive market orientation and new product success. Journal of Product Innovation and Management, 21(5), 334-344.

Müller Neto, H. F. (2005). Inovação orientada para o mercado: um estudo das relações entre orientação para mercado, inovação e performance. Doctoral dissertation, Universidade Federal do Rio Grande do Sul, Porto Alegre, RS, Brazil.

Oczkowski, E., \& Farrell, M. A. (1998). Discriminating between measurement scales using non-nested tests and two-stage least squares estimators: the case of market orientation. International Journal of Research in Marketing, 15(4), 349-366.

Pattikawa, L. H., Verwaal, E., \& Commandeur, H. R. (2006). Understanding new product project performance. European Journal of Marketing, 40(11/12), 1178-1193.

Perin, M. G. (2002). A relação entre orientação para mercado, aprendizagem organizacional e performance. Doctoral dissertation, Universidade Federal do Rio Grande do Sul, Porto Alegre, RS, Brazil. 
Perin, M. G., \& Sampaio, C. H. (2001, September). A relação entre as dimensões de orientação para mercado e a performance. Proceedings of the Encontro Nacional da Associação Nacional de Pós-Graduação e Pesquisa em Administração, Campinas, SP, Brazil, 25.

Perin, M. G., \& Sampaio, C. H. (2003, September). Orientação para o mercado, porte empresarial e performance: um estudo longitudinal no setor eletro eletrônico do Brasil. Proceedings of the Encontro Nacional da Associação Nacional de Pós-Graduação e Pesquisa em Administração, Atibaia, SP, Brazil, 27.

Perin, M. G., \& Sampaio, C. H. (2006, May). O papel da inovação na relação entre a orientação para o mercado e a performance empresarial. Proceedings of the Encontro de Marketing da Associação Nacional de Pós-Graduação e Pesquisa em Administração, Rio de Janeiro, RJ, Brazil, 2.

Perin, M. G., Sampaio, C. H., \& Faleiro, S. N. (2002, September). A relação entre orientação para o mercado, orientação para aprendizagem e inovação de produto. Proceedings of the Encontro Nacional da Associação Nacional de Pós-Graduação e Pesquisa em Administração, Salvador, BA, Brazil, 26.

Perin, M. G., Sampaio, C. H., \& Henriqson, E. (2005, September). Orientação para o mercado, orientação para aprendizagem e porte empresarial como antecedentes das dimensões da performance. Proceedings of the Encontro Nacional da Associação Nacional de PósGraduação e Pesquisa em Administração, Brasília, DF, Brazil, 29.

Perin, M. G., Sampaio, C. H., \& Hooley, G. J. (2006, September). Os recursos de marketing como antecedentes da performance. Proceedings of the Encontro Nacional da Associação Nacional de Pós-Graduação e Pesquisa em Administração, Salvador, BA, Brazil, 30.

Révillion, A. S. P. (2005). Inter-relações entre orientação para o cliente, cultura organizacional e cultura do varejo brasileiro e seu impacto no desempenho empresarial. Doctoral dissertation, Universidade Federal do Rio Grande do Sul, Porto Alegre, RS, Brazil.

Sampaio, C. H. (2000). Relação entre orientação para o Mercado e performance empresarial em empresas de varejo de vestuário do Brasil. Doctoral dissertation, Universidade Federal do Rio Grande do Sul, Porto Alegre, RS, Brazil.

Santos, G. J., \& Rossi, C. A. V. (2005, September). Market-oriented newspapers: possibilities to conciliate business performance parameters and the traditional values of journalism. Proceedings of the Encontro Nacional da Associação Nacional de Pós-Graduação e Pesquisa em Administração, Brasília, DF, Brazil, 29.

Shoham, A., Rose, G. M., \& Kropp, F. (2005). Market orientation and performance: a meta-analysis. Marketing Intelligence \& Planning, 23(5), 435-454.

Silva, F. A. C., Damacena, C., \& Melo, L. M. R. (2002). Orientação para o mercado e performance organizacional: um estudo na Indústria Vinícola do Rio Grande do Sul. Proceedings of the Congresso COPPEAD de Administração, Rio de Janeiro, RJ, Brazil, 9.

Slater, S. F., \& Narver, J. C. (1994a). Does competitive environment moderate the market orientationperformance relationship? Journal of Marketing, 58(1), 46-55.

Slater, S. F., \& Narver, J. C. (1994b). Market orientation, customer value and superior performance. Business Horizons, 37(2), 22-28.

Slater, S. F., \& Narver, J. C. (1995). Market orientation and the learning organization. Journal of Marketing, 59(3), 63-74. 
Slongo, L. A., \& Bossardi, G. (2004, September). Orientação para o mercado e qualidade de vida no trabalho: um estudo em empresas metalúrgicas, metal-mecânicas e de material elétrico de Caxias do Sul. Proceedings of the Encontro Nacional da Associação Nacional de PósGraduação e Pesquisa em Administração, Curitiba, PR, Brazil, 28.

Souza, A. C. R. (2004, September). A orientação para o marcado, o relacionamento com os clientes e o desempenho das empresas: um levantamento junto a empresas que atuam na região nordeste do Brasil. Proceedings of the Encontro Nacional da Associação Nacional de Pós-Graduação e Pesquisa em Administração, Curitiba, PR, Brazil, 28.

Urdan, A. T. (2000). O impacto da orientação para o mercado sobre o desempenho financeiro: as concessionárias de veículos da Fiat no Brasil (Relatório de Pesquisa No 15), São Paulo, SP, Brasil, Escola de Administração de Empresas de São Paulo, Núcleo de Pesquisas e Publicações, Fundação Getúlio Vargas.

Urdan, A. T. (2001a). O impacto da orientação para o mercado sobre o desempenho financeiro: as concessionárias de veículos da Ford e Volkswagen (Relatório de Pesquisa № 44), São Paulo, SP, Brasil, Escola de Administração de Empresas de São Paulo, Núcleo de Pesquisas e Publicações, Fundação Getúlio Vargas.

Urdan, A. T. (2001b). Orientação para o mercado e desempenho financeiro: o panorama das concessionárias General Motors no ramo automobilístico brasileiro (Relatório de Pesquisa $\mathrm{N}^{\mathrm{o}}$ 39), São Paulo, SP, Brasil, Escola de Administração de Empresas de São Paulo, Núcleo de Pesquisas e Publicações, Fundação Getúlio Vargas.

Vargo, S. L., \& Lusch, R. F. (2004). Evolving to a new dominant logic for marketing. Journal of Marketing, 68(1), 1-17.

Vazquez, R., Santos, M. L., \& Alvarez, L. I. (2001). Market orientation, innovation and competitive strategies in industrial firms. Journal of Strategic Marketing, 9(1), 69-90.

Viechtbauer, W. (2007). Hypothesis tests for population heterogeneity in meta-analysis. British Journal of Mathematical and Statistical Psychology, 60(1), 29-60. 